\title{
Modifikasi Model Chick Untuk Klorinasi Limbah Industri Dengan Berbagai Variasi Bakteri Dan Konsentrasi Klorin
}

\author{
Lukman Nulhakim*), Suparno , Dody Guntama, Afifah Suryono Putri dan Rahmat Hidayat \\ Teknik Kimia, Fakultas Teknologi Industri, Universitas Jayabaya \\ *) Corresponding author: lukman@ftijayabaya.ac.id
}

(Received: 29-Apr-2020 • Approved: 30-Apr-2020 • Accepted: 12-May-2020)

\begin{abstract}
Wastewater contains various kinds of microorganisms which are pathogenic (bacteria and viruses) which can be harmful to humans. The microorganisms can be removed by disinfection using chlorine. For disinfection tool design, in this study, a new kinetics model was formed to represent the data. The model is formed by developing the chick kinetics model combined with empirical equations (linear equations). The value of SSE at the assisted model is compared with existing kinetics models such as Hom and Has. Industrial wastewater sample added chlorine to the concentration of chlorine in wastewater at 0.05, 0.1, 0.15, 0.2, 0.25 ppm. Every 1, 2, 4, 6,8,10 and $20 \mathrm{~min}, 1 \mathrm{~mL}$ of the sample was calculated by the number of bacteria using the pour plate method. In this study, the resulting model can represent data well at concentrations of $0.1-0.25 \mathrm{ppm}$. The value of constants in kinetics such as $k$ is $0.725 \mathrm{~min}^{-1,}$ al is $2.6384 \mathrm{ppm}^{-1}$, and a2 is 0.2057. At a concentration of 0.1-0.25ppm, the model formed in this study is better at representing the data compared to the Hom and Has models.
\end{abstract}

\begin{abstract}
Abstrak
Air limbah mengandung berbagai macam mikroorganisme yang bersifat pathogen (bakteri dan virus) yang dapat membahayakan manusia. Mikroorganisme tersebut dapat dihilangkan dengan proses disinfeksi menggunakan klorin. Untuk peracancagan alat disinfeksi, pada penelitian ini dibentuk model kinetika baru untuk merepresentasikan data. Model dibentuk dengan mengembangakan model kinetika chick yang digabungkan dengan persamaan empiris (persamaan linier). Nilai SSE pada Model yang dibentuk dibandingkan dengan model kinetika yang sudah ada seperti Hom dan Has. Pada sampel air limbah Industri ditambahkan klorin hingga konsentrasi klorin di dalam air limbah sebesar $0,05,0,1,0,15,0,2,0,25 \mathrm{ppm}$. Setiap waktu 1, 2, 4, 6,8,10 dan 20 menit, $1 \mathrm{ml}$ sampel dihitung jumlah bakterinya dengan motode pour flate. Pada penelitian ini model yang dihasilkan dapat merepresentasikan dengan baik data pada konsentrasi $0,1-0,25 \mathrm{ppm}$. Nilai konstanta pada kinetika seperti k sebesar 0,725 menit ${ }^{-1}$, a1 sebesar 2,6384 ppm$^{-1}$ dan a2 sebesar 0,2057. Pada konsentrasi 0,1 $0,25 \mathrm{ppm}$, model yang dibentuk pada penelitian ini lebih baik merepresentasikan data dibandingkan dengan model Hom dan Has.
\end{abstract}

Keywords : Inactivation Kinetics, Wastewater, Bacteria, Disinfection, Mathamatical Modelling 


\section{PENDAHULUAN}

Air limbah mengandung berbagai macam mikroorganisme yang bersifat pathogen (bakteri dan virus) yang dapat membahayakan manusia. Oleh karena itu perlu penanganan khusus untuk mengolah air libah sebelum digunakan kembali. Proses inaktivasi dan penghancuran pathogen disebut dengan disinfeksi. Metode disinfeksi dapat dikategorikan menajadi 3 metode yaitu metode kimia, fisika dan radiasi. Disinfeksi dengan metode radiasi menggunakan sinar gamma yang sudah di teliti sejak lama, namun belum sampai tahap aplikasi pada limbah industri. Metode kimia dan fisika merupakan metode yang efektif untuk disinfeksi limbah industri. Pada metode kimia, senyawa kimia diumpankan ke dalam limbah indstri, untuk mempertahankan residu hingga waktu kontak yang diinginkan [1]. Senyawa kimia yang umum digunakan untuk proses disinfeksi adalah ozon $\left(\mathrm{O}_{3}\right)$, hidrogen peroksida $\left(\mathrm{H}_{2} \mathrm{O}_{2}\right)$, potasium permanganat $\left(\mathrm{KMnO}_{4}\right)$, peracetic acid (PAA) dan halogen. Senyawa halogen yang umum digunakan adalah senyawa klorin. Kelebihan dari senyawa klorin ini adalah selain sebagai disinfektan, senyawa klorin memiliki fungsi sebagai kontrol rasa dan bau, menghambat pertumbuhan alga, menghilangkan besi dan mangan, mendestruksi hydrogen sulfida [2]. Untuk merancang alat pada proses disinfeksi, maka konstanta kinetika perlu dicari. Konstanta kinetika dapat dicari dengan cara membuat model matematika pada fenomena yang terjadi. Model matematika yang umum digunakan untuk proses disinfeksi dengan klorin adalah model Chick [3] dimana model ini mengansumsikan proses inaktivasi mikrobiologi mengikuti reaksi kima orde pertama. Namun model ini tidak dapat digunakan ketika konsentrasi klorin pada pengolahan limbah tidak konstan serta klorin dikonsumsi oleh bakteri. Model Chick - Watson[4] dikembangkan agar dapat mewakili perubahan konsentrasi pada proses pengolahan limbah. Namun model tersebut memiliki kelemahan, karena tidak dapat digunakan ketika kandungan pathogen dalam limbah industri bervariasi. Model Hom [5] dan Has[6] dikembangkan untuk mewakili variasi pethogen dan konsentasi klorin. Nilai kontanta kinetika pada model yang telah dibuat dapat dicari dengan metode analisis differensial, integral dan regresi non linear[7]. Penelitian ini bertujuan untuk mengembangkan model chick, dimana persamaan Chick digabungkan dengan persamaan empiris (persamaan linear) agar dapat digunakan ketika kondisi konsentrasi klorin dan phatogen yang bervariasi. Selain itu model yang dikembangkan pada penelitian ini dibandingkan dengan model Hom dan Has, sehingga ditemukan nilai parameter terbaik untuk perancangan alat.

\section{METODE PENELITIAN}

\section{Bahan}

Pada Penelitian ini sampel limbah industri diambil dari keluaran air limbah pada proses secondary treatment di PT. Pfizer Indonesia, Sedangkan bahan kimia yang digunakan adalah sebagai berikut: Sodium Hipoklorit $(\mathrm{NaClO}, 10 \%)$ berasal dari PT. Asahimas Chemical Indonesia, Agar mikrobiologi berasal dari Merck.

\section{Metode}

Sebanyak 1L air sampel diambil dari air limbah industri, kemudian sebanyak $100 \mathrm{ml}$ air sampel di dalam tabung kimia diatur konsentrasi klorinnya sebesar 0,05 ppm, 0,1 ppm, 0,15 ppm, 0,2 ppm dan 0,25 ppm. Kemudian kocok dengan pengocok mekanis selama 1, 2, 4, 
$6,8,10,20$ menit. Setiap sampel dianalisa jumlah bakterinya dengan metode pour plate secara duplo [8] seperti di bawah ini:

Satu mililiter larutan dari badan cairan dibuat pengenceran bahan kelipatan 10, dari masing - masing pengenceran diambil $1 \mathrm{cc}$ dan dibuat taburan dalam petry dish (pour plate) dengan medium agar $48-50^{\circ} \mathrm{C}$, setelah diinkubasi pada suhu ruang selama 24 jam dihitung jumlah koloni dari masing -masing pengenceran. Dari jumlah koloni tiap petry dish dapat ditentukan jumlah bakteri tiap cc dengan menggunakan persamaan berikut [8]:

Jumlah bakteri dalam sampel $=\frac{\text { Jumlah bakteri dalam petri dish }}{\text { Jumlah petri } \mathrm{X} \text { Banyaknya pengenceran }}$

Perhitungan jumlah koloni dalam petry dish dilakukan dalam colony counter. Pada perhitungan dengan cara ini diperlukan beberapa syarat yang harus dipenuhi antara lain:

1. Jumlah koloni tiap petry dish antara 30-300 koloni, jika memang tidak ada yang memenuhi syarat dipilih jumlahnya yang mendekati 300 .

2. Tidak ada koloni yang menutup lebih besar dari setengah luas petry dish, koloni tersebut dikenal sebagai spreader.

3. Perbandingan jumlah bakteri dari hasil pengenceran yang berturut-turut antara pengenceran yang lebih besar dengan pengenceran sebelumnya, jika sama atau lebih kecil dari 2 hasilnya dirata-rata; tetapi jika lebih besar dari 2 yang dipakai jumlah mikrobia dari hasil pengenceran sebelumnya.

Jika dengan ulangan memenuhi syarat hasilnya dirata-rata [8].

\section{Model Matematika}

Berdasarkan data Jumlah bakteri yang terhitung, dilakukan kurve fiting dengan model matematika yang telah dibuat. Pada penelitian ini, persamaan Chick seperti pada persamaan 2 dikembangkan dengan cara mengasumsikan orde (n) dari waktu dan dinyatakan sebagai fungsi dari konsentrasi dengan persamaan linear seperti pada persamaan 3 .

$$
\begin{aligned}
& N=N_{0} e^{-k t^{n}} \\
& n=a_{1} C+a_{2}
\end{aligned}
$$

Nilai konstanta di atas dicari dengan metode regresi non linear seperti pada Gambar 1 menggunakan software MS.Excel [9]. Nilai SSE pada persamaan Hom (persamaan 4) dan Has (persamaan 5).yang didapat dibandingkan dengan hasil yang didapat dari model modifikasi model chick (persamaan 2)

$$
\begin{aligned}
& N=N_{0} \exp \left[-k^{n} C^{n} t^{m}\right] \\
& N=N_{0} \exp \left[-\left(\frac{m}{n k_{c}}\right)^{m} k^{m} C_{0}^{n}\left(1-e^{-\frac{n k_{c} t}{m}}\right)^{m}\right]
\end{aligned}
$$




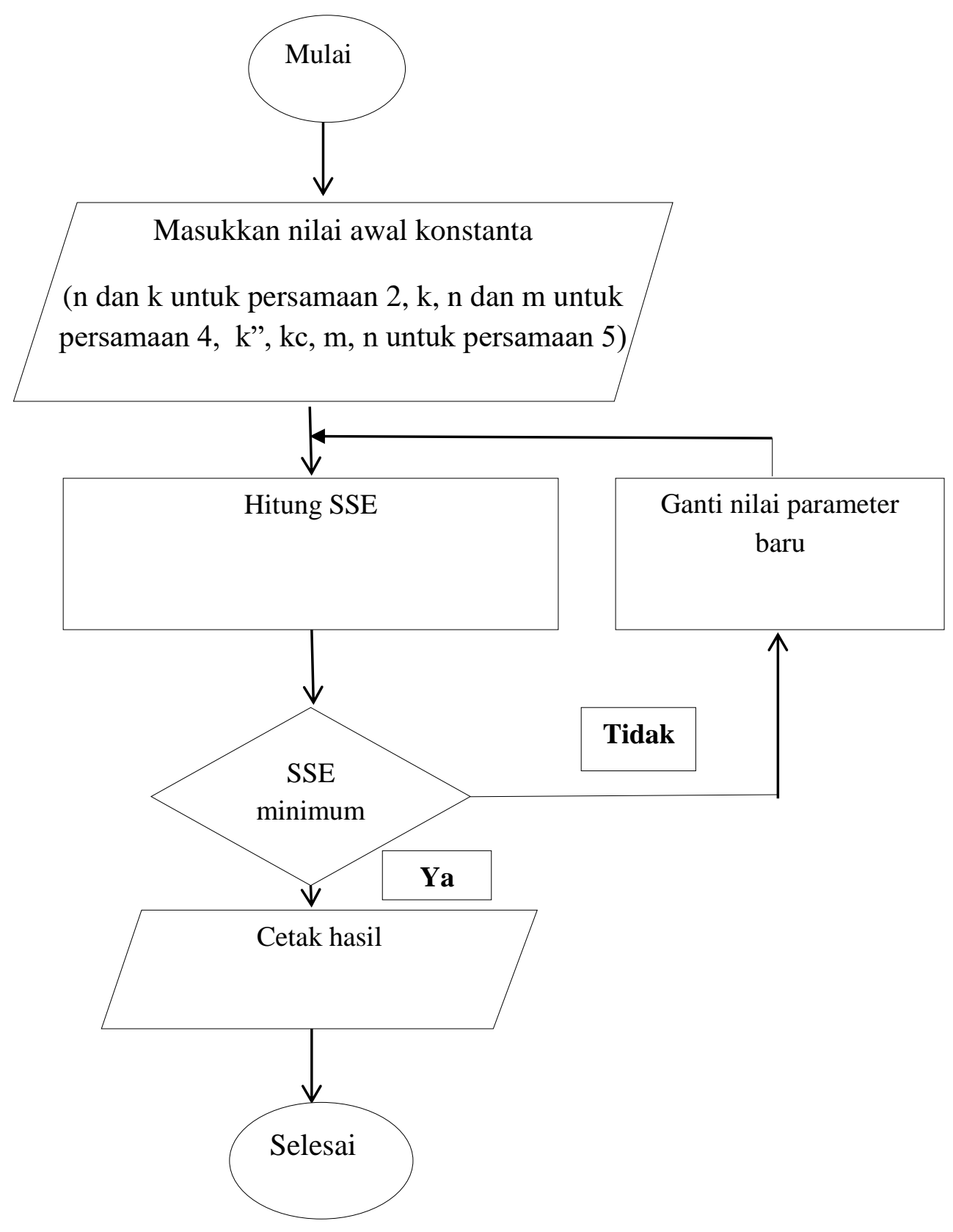

Gambar 1. Algortima Pencarian Konstanta Reaksi Dengan Metode Regresi Nonlinear

\section{HASIL DAN PEMBAHASAN}

Air limbah yang sudah di alirkan melalui tahap primary dan secondary treatment (air sampel) kemudian dihitung jumlah bakteri yang terkadung didalamnya. Jumlah bakteri yang terkandung didalam limbah tersebut sebanyak $144 \mathrm{CFU} / \mathrm{mL}$. Bakteri yang hidup dalam air sampel beranekaragam, hal ini dapat dilihat dari ketika bakteri dalam sampel dikembang biakan dalam agar membentuk koloni dengan bentuk dan warna yang beranekaragam seperti yang ditunjukkan pada Gambar 2. 


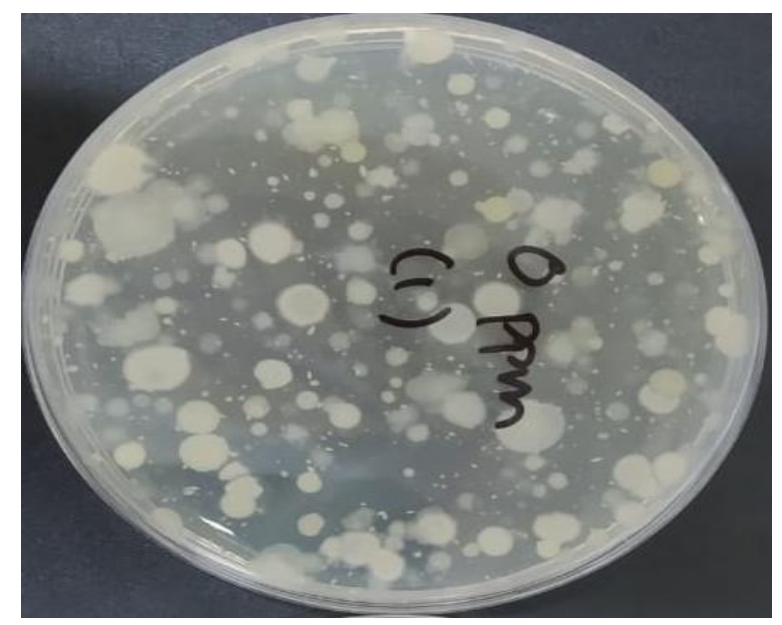

Gambar 2. Koloni - koloni bakteri dalam air sampel yang dikembangbiakan dalam Agar

Berdasarkan Standar baku mutu air limbah menggunakan Peraturan Menteri Lingkungan Hidup dan Kehutanan Republik Indonesia Nomor. P.68/Menlhk/Setjen/Kum.1/8/2016 [10], Jumlah maksimal bakteri pada air limbah industri sebesar $30 \mathrm{CFU} / \mathrm{mL}$. Air limbah yang sudah di alirkan melalui tahap primary dan secondary treatment perlu diturunkan agar sesuai standar, menggunakan proses disinfeksi dengan klorin. Pada Tabel 1 dapat dilihat jumlah bakteri yang tersisa setelah proses disinfeksi pada berbagai waktu dan konsentrasi klorin. Ketika klorin di masukan ke dalam sampel, klorine dapat membunuh bakteri dengan baik hal ini ditunjukkan dengan jumlah bakteri yang bekurang ketika sampel ditambahkan klorine, dimana sebanyak $91 \%$ bakteri mati ketika konsentrasi klorin 0,25 ppm dalam waktu kontak 20 menit. Pada bekteri, klorin merusak dinding sel, mengubah permeabilitas sel (kemampuan untuk membuang air masuk dan keluar melalui dinding sel), mengubah protoplasma sel, menghambat aktivitas enzim sel sehinga tidak dapat menggunakan makanannya untuk menghasilkan energi, menghambat reproduksi sel [11]. Pada bakteri Escherichia Coli dan Candida, klorin menyebabkan kehancuran dinding membran sel, menyebabkan kebocoran sel membran dan menyebakan sintesis DNA yang lebih rendah [12]. Reaksi antara klorin dan mikroorganisme tidak bejalan secara instan, namun membutuhkan beberapa waktu. Hal ini ditunjukkan ketika waktu kontak antara klorin dan bakteri sebesar 1 menit jumlah bakteri cukup banyak, namun setelah 20 menit jumlah bakteri yang hidup bekurang drastis. 
Tabel 1. Jumlah Bakteri dari Hasil Analisa Pour Plate Pada Sample Air $\left(\mathrm{CFU} \mathrm{mL} \mathrm{mL}^{-1}\right)$

\begin{tabular}{ccccccc}
\hline Waktu (menit) & \multicolumn{6}{c}{ Konsentrasi Cl2 (ppm) } \\
& 0 & 0.05 & 0.10 & 0.15 & 0.20 & 0.25 \\
\hline 0 & 144 & 144 & 144 & 144 & 144 & 144 \\
1 & & 97 & 71 & 70 & 70 & 68 \\
2 & & 84 & 69 & 66 & 61 & 58 \\
4 & & 84 & 66 & 65 & 44 & 24 \\
8 & & 80 & 65 & 60 & 37 & 22 \\
10 & & 78 & 60 & 44 & 29 & 20 \\
20 & 76 & 58 & 32 & 28 & 13 \\
\hline
\end{tabular}

Nilai konstanta kinetika didapatkan dengan melakukan regresi nonlinear (curve fitting) seperti pada Gambar 3, 5, 6 dan 7. Gambar 4 merupanakn regresi nonlinear untuk model yang dikembangkan pada penelitian ini. Model yang di kembangkan dapat dengan baik merepresentasikan data pada konsentasi $0,1 \mathrm{ppm}$ hingga $0,25 \mathrm{ppm}$, dimana didapatkan nilai kontanta reaksi sebesar 0,725 dan nilai $n$ yang barvariasi seperti yang ditunjukkan pada Gambar 4.

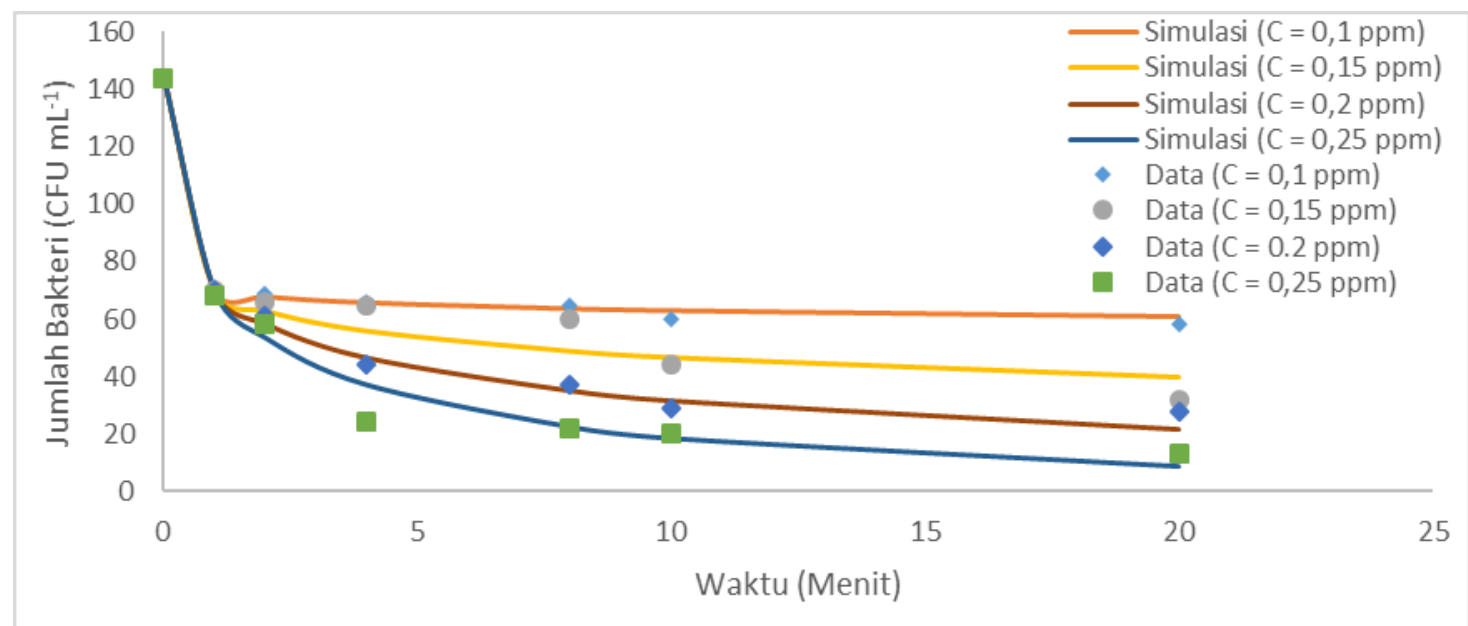

Gambar 3. Grafik Curve Fitting Data Eksperimen Dengan Model Kinetika Yang Dikembangkan Pada Penelitian Ini (Konsentrasi Klorin 0,1-0,25 ppm) 


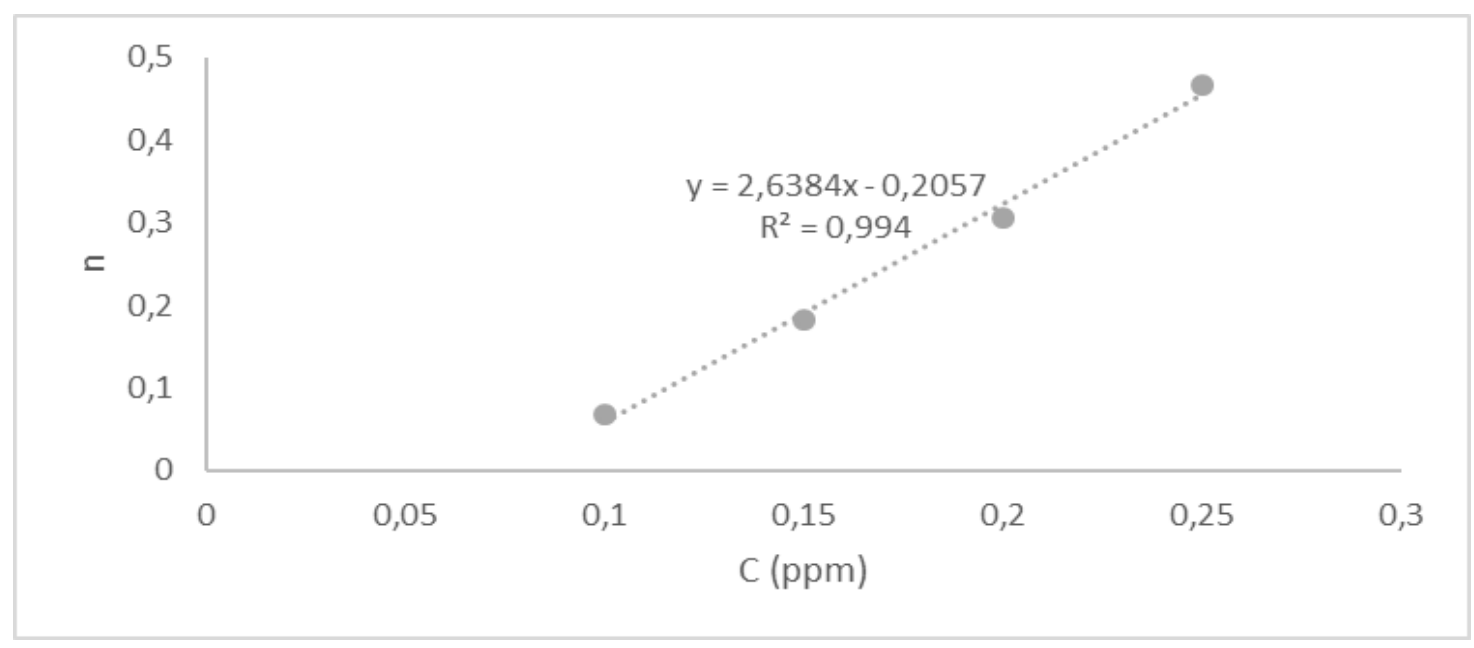

Gambar 4. Grafik Hubungan Nilai n Pada Berbagai Konsentrasi Klorin

Kontanta n merupakan kontanta empiris yang didapatkan dari regresi non linier, pada penelitin ini nilai $\mathrm{n}$ dinyatakan sebagai fungsi dari konsentrasi klorin. Nilai $\mathrm{n}$ yang didapatkan meningkat seiring dengan meningkatnya nilai dari konsentrasi klorin. Dengan menggunakan regresi linear maka didapatkan nilia $n$ fungsi dari konsentrasi, yakni $n=2,6383 \mathrm{C}-0,2057$, sehingga nilai a1 adalah 2,6383 $\left(\mathrm{ppm}^{-1}\right)$ dan nilai a2 adalah 0,2057. Namun model ini tidak dapat merepresentasikan dengan baik ketika konsentrasi kecil yakni saat konsentrasi klorin sebesar 0,05 ppm. Hal ini dikarenakan pada konsentrasi rendah clorin tidak terlalu efektif meninaktivasi mikroorganisme, seperti yang ditunjukkan pada Gambar 5 jumlah bakteri yang tidak terinaktivasi masih cukup tinggi. Nilai k pada konsentrasi $0,05 \mathrm{ppm}$ sebesar $0,441 \mathrm{~min}^{-1}$ dan $\mathrm{n}$ sebesar 0,1363 . Nilai $\mathrm{k}\left(0,441\right.$ menit $\left.^{-1}\right)$ yang lebih kecil dibandingkan nilai $\mathrm{k}$ yang didapatkan pada konsentrasi tinggi $\left(0,725\right.$ menit $\left.^{-1}\right)$ menunjukkan pada kosentrasi klorin 0,05 ppm laju inaktivasi mikroorganisme yang lebih rendah.

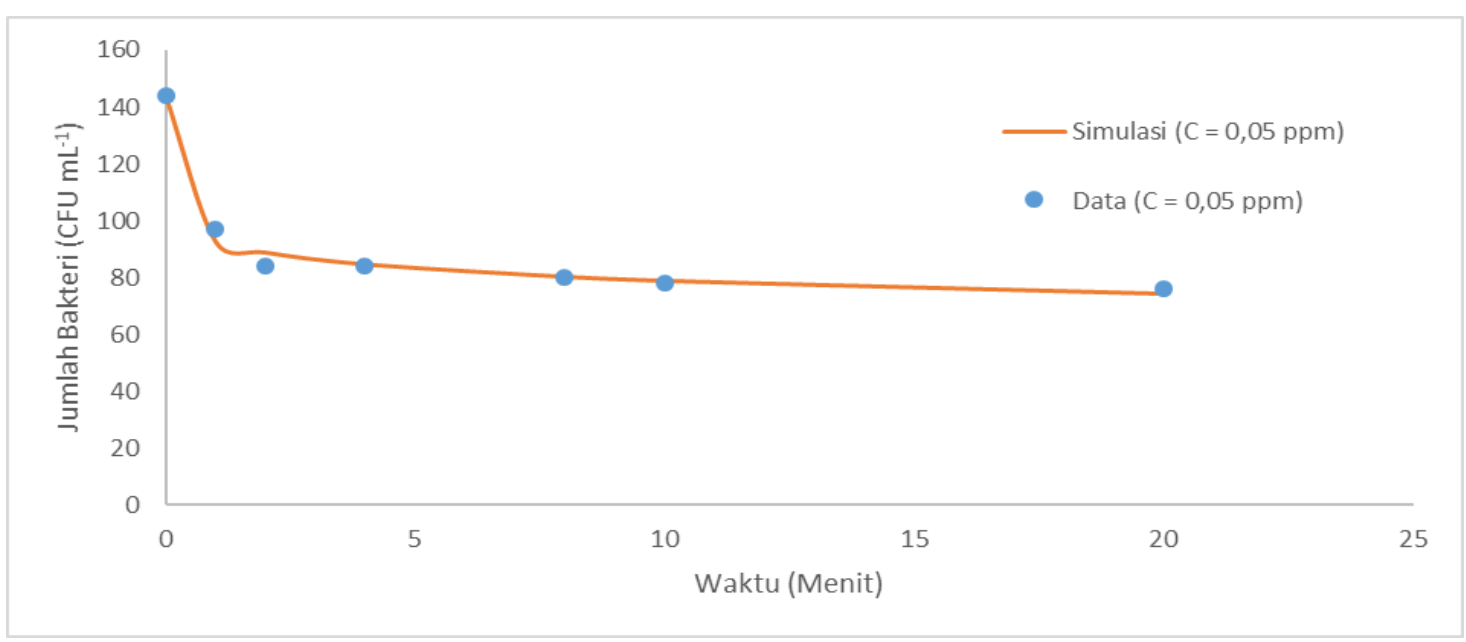

Gambar 5. Grafik Curve Fitting Data Eksperimen Dengan Model Kinetika Yang Dikembangkan Pada Penelitian Ini (Konsentrasi Klorin 0,05 ppm) 
Model Hom [4] dan Has[5] digunakan pada penelitian ini untuk merepresentasikan data yang didapat pada eksperimen seperti yang ditunjukkan pada Gambar 6 dan 7. Model hom dan Has dapat merepresentasikan dengan baik data kinetika inactivasi microorganisme baik menggunakan klorin konsentrasi kecil hingga tinggi, nilai konstanta kinetika yang didapatkan dapat dilihat pada Tabel 2. Hal ini membuktikan bahwa model Hom cocok digunakan untuk kondisi dimana di dalam limbah terkandung banyak variasi organisme. Hal serupa di tunjukkan dalam penelitan [5 \& 13 ], dimana model Hom sukses mendeskripsikan kientika inaktivasi untuk variasi pathogen, termasuk virus dan protozoa.

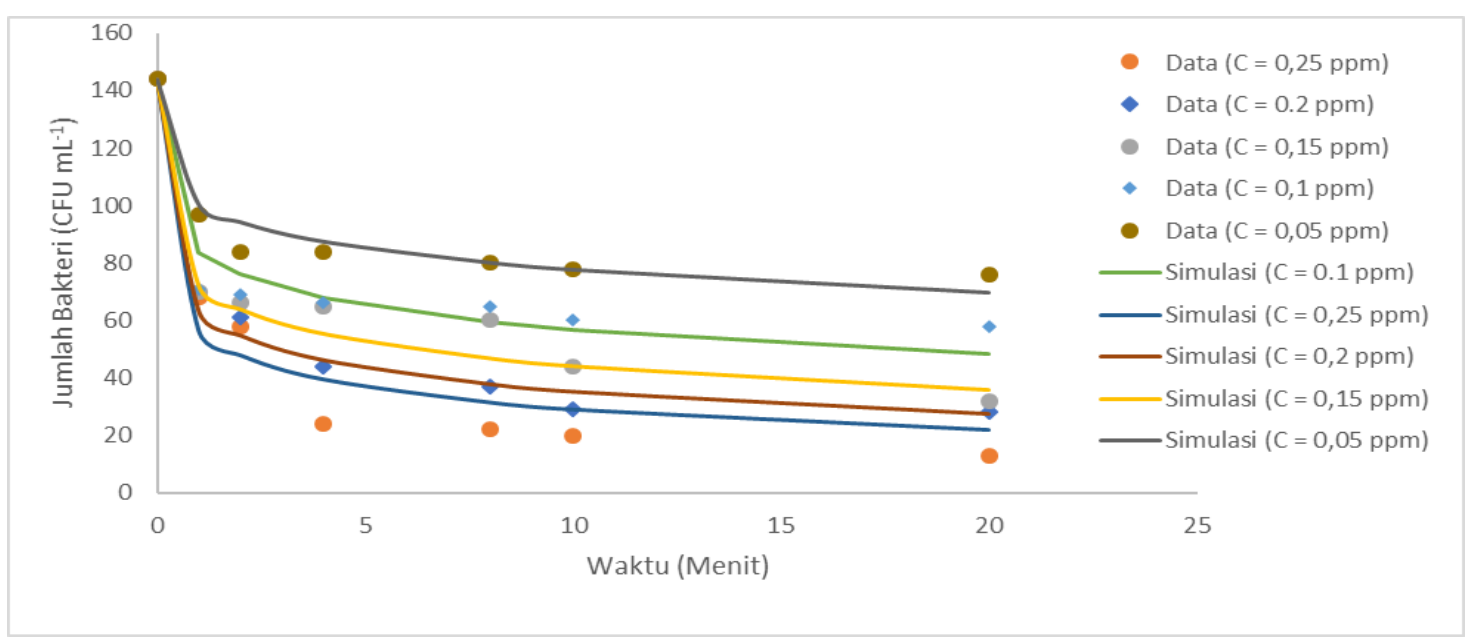

Gambar 6. Grafik Curve Fitting Data Eksperimen Dengan Model Hom

Model Has merupakan model yang dikembangkan dari model Hom, dimana model ini melibatkan reaksi orde satu pada kerusakan klorin fungsi dari waktu terhadap proses inaktivasi bakteri [6, 14-16]. Pada penelelitian ini, model Has lebih baik dalam mendeskirpsikan data karena nilai SSE yang didapatkan lebih kecil dari pada model Hom, seperti yang ditunjukkan pada Tabel 2. Nilai Sum Square of Erorr (SSE) dari masing masing model menunjukkan bahwa seberapa besar error antara model dan data eksperiment.

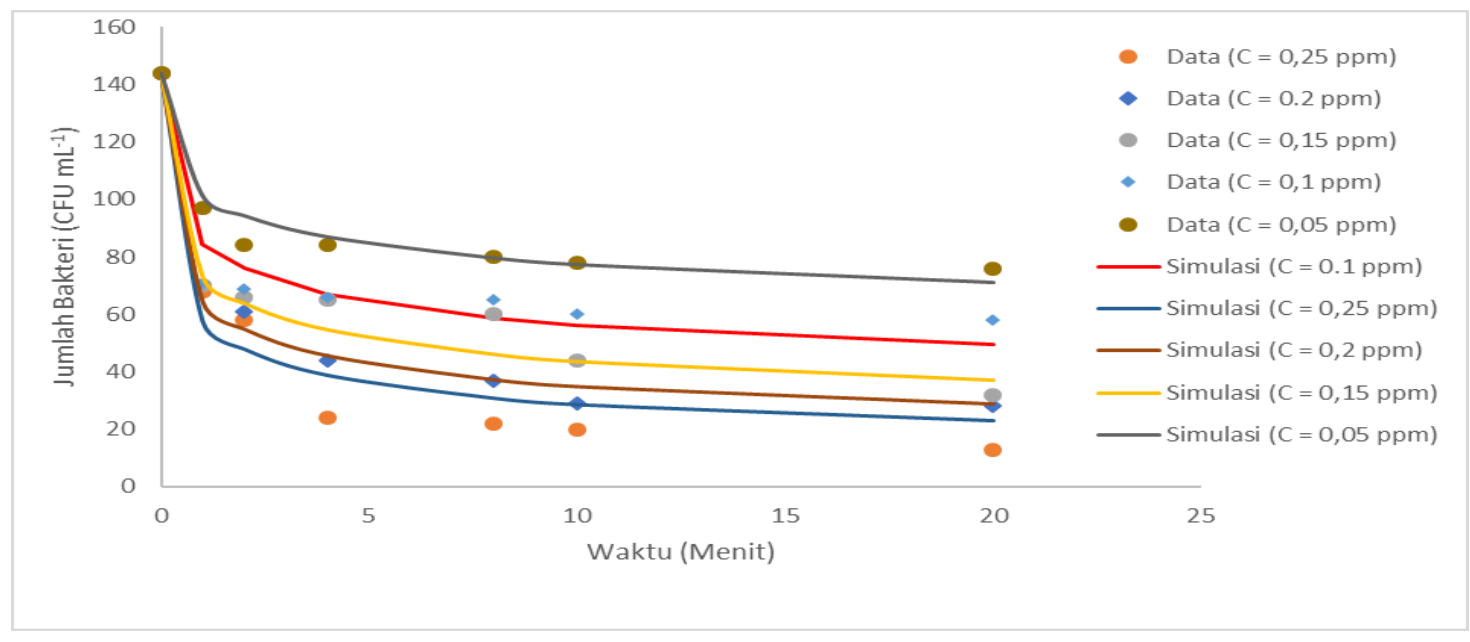

Gambar 7. Grafik Curve Fitting Data Eksperimen Dengan Model Han 
Nilai SSE terkecil dari ketiga model adalah model yang dikembangkan pada penelitian ini. Nilai SSE pada model yang dikembangkan pada penelitian ini sebesar 583 jauh lebih kecil dibandingkan model Hom dan Has, sehingga model pada penelitian ini jauh lebih baik dibandingkan model Hom dan Has pada konsentrasi klorin di atas 1 ppm.

Tabel 2, Nilai Konstanta Kinetika Dan SSE Pada Berbagai Model.

\begin{tabular}{cccccc}
\hline \multicolumn{2}{c}{ Model Pada Penelitian ini } & \multicolumn{2}{c}{ Model Hom } & \multicolumn{2}{c}{ Model Has } \\
Konstanta & Nilai & Konstanta & Nilai & Konstanta & Nilai \\
\hline $\mathrm{K}$ & 0,725 menit $^{-1}$ & $\mathrm{k}$ & 2,1294 menit $^{-1}$ & $\mathrm{k}$ " & $2,1051 \mathrm{ppm} \mathrm{menit}^{-1}$ \\
$\mathrm{a} 1$ & 2,6384 & $\mathrm{n}$ & 0,5928 & $\mathrm{kc}$ & $0,0241 \mathrm{menit}^{-1}$ \\
$\mathrm{a} 2$ & 0,2057 & $\mathrm{~m}$ & 0,234 & $\mathrm{~m}$ & 0,2727 \\
$\mathrm{SSE}$ & 583 & SSE & 1640 & $\mathrm{n}$ & 0,5926 \\
& & & & $\mathrm{SSE}$ & 1434 \\
\hline
\end{tabular}

\section{KESIMPULAN}

Modifikasi model Chick dapat merepresentasikan dengan baik data kinetika inaktivasi mirkrooraganisme dalam air limbah dengan vasirasi konsentrasi klorin dan jenis bakteri. Model yang dikembangkan pada penelitian ini dapat merepresentasikan data lebih baik dibandingkan dengan model Hom dan Has. Nilai konstanta pada kinetika seperti k sebesar 0,725 (menit $\left.{ }^{-1}\right)$, a1 sebesar 2,6384 (ppm-1) dan a2 sebesar 0,2057.

\section{UCAPAN TERIMAKASIH}

Kami ucapkan terimakasih kepada FTI-UJ dan PT. Pfizer Indonesia, atas Izin dan dukungan fasilitas yang diberikan, sehingga penelitian ini dapat terselesaikan.

\section{DAFTAR NOTASI}

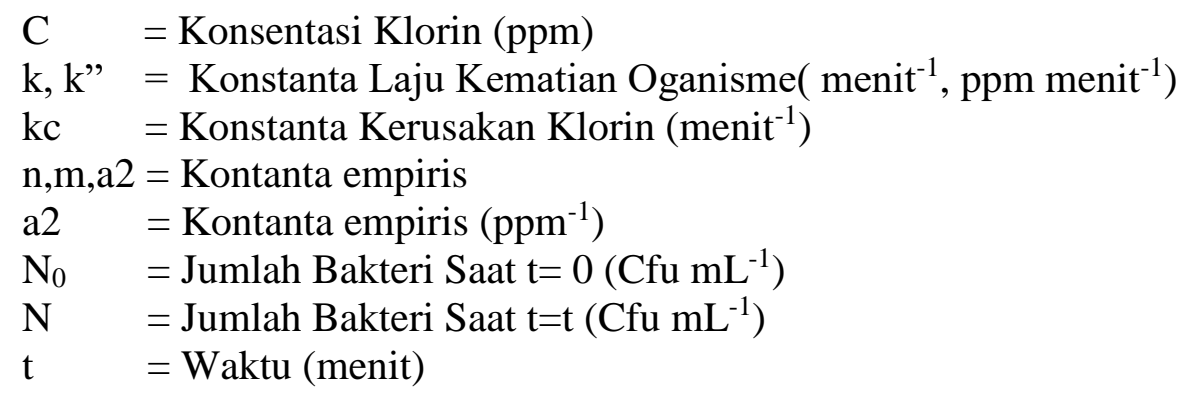




\section{DAFTAR PUSTAKA}

[1] S. R. Qasim, Wastewater Treatment and Reuse Theory and Design Examples, Volume 2: Post-Treatment, Reuse, and Disposal, Guang Zhu: CRC Press, 2018.

[2] W. G. Clifford, Handbook of Chlorination and Alternative Disinfectants, New York: Van Nostrand Reinhold, 1992.

[3] H. Chick, "An Investigation of the Laws of Disinfection," Journal of Hygiene, vol. 8, pp. 92-157, 1908.

[4] . H. E. Watson, "A note on the variation of the rate of disinfection with change in the concentration of disinfectant,", journal of hygiene, vol. 8, pp. 536-542, 1908.

[5] L. W. Hom, "Kinetics of Chlorine Disinfection of an Ecosystem," Journal of the Sanitary Engineering Division, vol. 98, pp. 183-194, 1972.

[6] C. N. Haas and J. Joffe, "Disinfection Under Dynamic Conditions: Modification of Hom's Model for Decay," Environmental Science and Technology, vol. 28, p. 7, 1994.

[7] H. S. Fogler, Elements of Chemical Reaction Engineering, Fifth Edition, New York: Prentice Hall, 2016.

[8] Jutono, . J. Soedarsono and S. Hartadi, Pedoman Preaktikum Mikrobiologi Umum Untuk Perguruan Tinggi, Yogyakarta: Departement Microbiologi, Fakultas Pertanian, Universitas Gadjah Mada, 1980.

[9] R. W. Larsen, Engineering with Excel, Boston: Pearson, 2012.

[10] Menteri-Lingkungan-Hidup-Dan-Kehutanan-Rekpublik-Indonesia,"PERATURAN MENTERI LINGKUNGAN HIDUP DAN KEHUTANAN REPUBLIK INDONESIA NOMOR: P.68/Menlhk-Setjen/2016 TENATANG BAKU MUTU AIR LIMBAH DOMESTIK," Jakarta, 2016.

[11] F. R. Spellman, Handbook of Chemical Engineering Calculations, Florida: Taylor \& Francis, 2014.

[12] C. N. Hass and R. S. Englebrecht, "Physiological alterations of vegetative microorganisms resulting from aqueous chlorination," J. Water Pollut, vol. 52, no. 7, 1980.

[13] C. N. Haas and S. Lingireddy, "General kinetics of disinfection processes," in Control of Microorganisms in Drinking Water, Reston, ASCE, 2002.

[14] C. N. Haas, M. S. Heath, J. Jcangelo and U. J. Joffe, Development and Validation of Rational Design Methods of Disinfection, Denver: American Water Works Association (AWWA) and the AWWA Research Foundation (AwwaRF), 1995.

[15] M. W. LeChevallier and K. Au , Water Treatment and Pathogen Control: Process Efficiency in Achieving Safe Drinking Water, London: World Health Organization (WHO)/IWA Publishing, 2004.

[16] K. J. Howe, D. W. Hand and J. C. Crittenden, Principles of Water Treatmen, Hoboken: John Wiley \& Sons, 2012. 